\title{
Performance Assessment on High School Advanced Algebra
}

\author{
Santa Tejeda ${ }^{a}$ and Katherina Gallardo ${ }^{a}$ \\ aRegional Science Department - Tecnologico de Monterrey (ITESM), Nuevo Leon, MÉXICO; \\ bHumanities and Education School - Tecnologico de Monterrey (ITESM), Nuevo Leon, MÉXICO
}

\begin{abstract}
The lack of feedback in the student-teacher relationship creates an incomplete perspective about the learning process in Mathematics, as for example in Advanced Algebra. This research was conducted in Mexico using a theoretical framework for performance assessment, based on the competencies for Advanced Algebra learning at the high school level. The objective sought to explore students' perceptions after a performance assessment process, using two groups of students who took Advanced Algebra for the second time because of low academic achievement. Mixed methods research was selected for understanding profoundly how performance assessment reports (PAR) could bring useful information to students for reaching expected performance levels. A performance rubric based on Marzano and Kendall's New Taxonomy, as well as semi-structured interviews, were used for data collection purposes. The findings confirm that changing the assessment method from traditional grading to performance assessing can be a clearer approach for understanding students' strengths and weakness as Advanced Algebra learners.
\end{abstract}

KEYWORDS

Advanced Algebra, performance assessment, competencies, high school, feedback
ARTICLE HISTORY

Received 15 September 2017

Revised 10 October 2017

Accepted 10 November 2017

\section{Introduction}

Mathematical competencies have been introducing with popularity among schools around the world since the Organisation for Economic Co-operation and Development (OECD) initiated its Programme for International Student Assessment (PISA), which challenges students to demonstrate not just their capabilities for solving an operation or an equation, but for discussing and applying its usage for solving real-life situations. The seven general mathematical competencies established by OECD (2017) are communication;

\section{CORRESPONDENCE Santa Tejeda $\square$ stejeda@itesm.mx}

(C) 2017 S. Tejeda \& K. Gallardo

Open Access terms of the Creative Commons Attribution 4.0 International License apply. The license permits unrestricted use, distribution, and reproduction in any medium, on the condition that users give exact credit to the original author(s) and the source, provide a link to the Creative Commons license, and indicate if they made any changes. (http://creativecommons.org/licenses/by/4.0/) 
mathematising; representation; reasoning and argument; strategic thinking; and using symbolic, formal, technical language and operations, and using mathematical tools. Working on these competencies for becoming a mathematically literate student would make it possible for them to recognize that mathematics calls for prior knowledge, so as to make well-founded judgments and decisions needed by constructive, engaged, and reflective citizens.

OECD's argument has become an actual worldwide goal for math elementary and secondary teachers. Nevertheless, educational systems and assessment methodologies are not moving quite fast enough to shape teaching practices so as to fit into this scope's demands. For this reason, it is sometimes hard to transfer all of this new approach into new classroom practices. One of these new practices is related to performance assessment procedures (Hancock, 2007; Palm, 2008). This research article is intended to share the main results of a transformation teaching process that is focused on performance assessment, specifically for high school groups taking Advanced Algebra lessons.

\section{Advanced Algebra competence development}

Algebra is an area of mathematics that is taught from the first year of secondary school until high-school years. This means that secondary students meet, for the first time, basic algebraic concepts. As this knowledge will become the basis for Pre-calculus, algebraic concepts act like foundations that can be either bricks or holes that inexplicably can help or obstruct students' learning.

Many teachers and researchers ask themselves why students who practice and solve mathematical problems during a semester fail, even when they appear to be outstanding learners. There are so many approaches towards answering this question; for example, problem-solving (Polya, 1957; Schoenfeld, 2007), modelling (Lesh \& Doerr, 2003), representations (Duval, 2006), and concept definition and image (Vinner, 1983). Even if these approaches are useful, it is convenient to go deep into the details as to how the performance emerges.

In fact, Star and Rittle-Johnson (2009) affirm that the ability to reason, explore, operate, and manipulate symbols can be understood like algebra. In addition, these authors mention that researchers can be interested in how students advance in gaining dominance in these activities. From this perspective, it is mandatory to research the highest level of performance that a student may attain. This work proposes to explore these levels in terms of competencies through specific tasks. According to Vega-Castro, Molina, and Castro (2012), it is helpful to find the holes in the expected mathematics level and obtain a structural sense, if there is one.

To understand Advanced Algebra processes in a deeper way and how students develop their knowledge and abilities to cope with them, it was necessary to define the main competencies as well as their subcompetencies based on the Mexican national educational math plan for the high-school level (SEP, 2008). Table 1 shows the three competencies established for Advanced Algebra, as well as their subcompetencies.

Table 1: Classification of competencies and their descriptions 


Competencies Short name and code Subcompetencies

1. Interprets mathematical models through the application of arithmetic, algebraic, geometric understanding and analysis of real or hypothetical situations. procedures for the

\author{
Application of sequences (IM- I. In addition to identifying functions \\ D1) \\ and / or variables, the student \\ algebraically simplifies the new \\ function and clears the unknown \\ variable.
}

Integration of steps in the general strategy of solving a problem (IM-D2)

II. The student graphs the solution of problems related to inverse functions or composite functions that include rank, domain and vertex in a Cartesian plane. The student can also express the answer in writing.

III. The student graphs the characteristics of the functions: absolute value, exponential, logarithmic, conic. exponential, logarithmic and conic functions according to the characteristics of the graph (IM-D3)

2. Solve mathematical problems by applying arithmetic, algebra, and geometry

Function evaluation (RP-D1)

Redefining a function in terms of the number to be evaluated

(RP-D2)

3. Explain and interpret the results obtained Interpretation of the result of an algebraic expression evaluated (IR-D1)
V. The student applies a process of insertion of values to evaluate conical functions.

IV. The student applies processes of substitution and simplification of composite and logarithmic functions through mathematical procedures and contrast them with established models or real situations specific to their experiences.
VI. The student justifies the answer according to the variables of the problem of the piecewise and exponential function.

These subcompetencies permit a series of learning activities to be planned and problems to be solved according to topic; they are explained as follows. First, Application of sequences, is the need to know that a sequence is a series of actions that allow the student to relate and / or alter a mathematical object to solve an unknown element associated with this object. A sequence allows seeing 
relationships between properties and between concepts, such as functions or mappings (Vollrath, 1984). The knowledge and mastery of a sequence has repercussions on the development of a work style focused on solving a mathematical problem (Weigand, 2004).

Second, Integration of steps in the general strategy of solving a problem, is the lining up of the mathematical steps in order to make sense of the big picture of the whole problem. In this course, it is essential to relate the algebraic representation to its graphic representation, because of the nature of the curriculum. The intention of the Advanced Algebra course is that the student extends the mathematical representation of a function, so there many word problems are associated with graphical problems and vice versa. Schoenfeld (2007) explains that solving a problem carries one through different stages before giving the result. These stages can be analyzed through different mental activities, which are reflected through logical actions and arguments in mathematics. For a student to demonstrate the change of representation between an equation and a graph, he or she needs to provide oral or written evidence (at least) of a logical argument or a graphical representation.

Third, Application of forms and characteristics of exponential, logarithmic and conic functions according to the characteristics of the graph, is the case in which the student has to recognize, analyze, complete and solve an algebraic or graphical problem involving one or more of these functions. The teacher presents and solves a few problems of this type, and then assigns more problems with each of the graphic elements, as for example: positive and negative signs; the direction, exponent and base; or peculiar forms like absolute value (Bayazit, 2010). In addition, real situations receive some attention in class, but this is not imperative.

Fourth is Function evaluation. The function, according to Godino, Castro, Aké, and Wilhelmi (2012) is a basic mathematical concept that favors the learning of other more abstract and elaborated concepts, such as calculus. For a student, it is elemental to identify and give meaning to the intrinsic processes of the function, such as its evaluation, so as to understand it. Operatively, it is easy for the student to see substitution, simplification, and similar fundamental processes for manipulating a function, but this does not imply that the student is making sense of the function. Carlson, Oehrtman, and Engelke (2010) state that the student tends to assign two meanings to the function: as a process and as a symbolic manipulation, which means the student does not usually interpret the result as a numerical output of a function. The authors mention that, beyond merely understanding the meaning of a number, the student lacks the ability to relate the input to the output data of a function, or what they call "covariational reasoning."

Fifth, Redefining a function in terms of the number to be evaluated, retakes the application of conceptual elements of conic functions towards solving problems, based on the conditions of each problem. The student works with conic functions according to the structures present in each function, and which progressively increase in order of difficulty (Godino et al., 2012). For example, a good place for the student to start his or her study is the circle, which by its simplicity allows him or her to work easily with its algebraic elements. It is feasible then to study the parabola, as it is a concept known to the student, 
although it has more elements than the circle, which was the first conic function. Difficulty is increased and competence is developed with the ellipse and hyperbola, as they are more abstract functions that are only understood by fully relating the algebraic and graphic representations.

Finally, Interpretation of the result of an algebraic expression evaluated result, is closely related to the fourth subcompetency. It is the interpretation of the result of the evaluation of a function, a process that involves a sense of being able to go back and forth in the substitution of a function. The reasoning necessary to perform this activity implies the assimilation of the result of the evaluation of a function from the input data to the final result and vice versa. In other words, to interpret the change or correlation between variables globally, according to Oehrtman, Carlson, and Thompson (2008).

\section{Performance assessment}

Competency based education (CBE) demands performance assessment procedures. This type of assessment helps determine whether a student can apply what he or she knows to real-life situations. Thus, students are required to demonstrate acquisition of knowledge and skills in one or more content areas rather than answer questions in a quiz or write an essay. An important feature of performance assessment is that it involves the student deeply. If it is well conducted, it can help students reach good levels for skills and abilities development (Frey, Schmitt, \& Allen, 2012; Hancock, 2007; Klein-Collins, 2013).

Bahr (2007) proposed a way to operationalize mathematics performance assessment in six steps: (1) Choose topics from the educational grade; (2) Write an engaging, real-life world problem that incorporates the chosen concepts; (3) Design a quickly administered inventory to estimate performance level; (4) Select criteria to serve as standards for judging the performance; (5) Design a rubric using those criteria; (6) Create questions or prompts to probe student thinking; and (7) Create both a form for students to record their work and a teacher recording form.

Educational research in this specific topic has been conducted recently from different perspectives. Examples include positive biases in self-assessment of mathematics competence, achievement goals, and mathematics performance (Dupeyrat, Escribe, Huet, \& Regner, 2011); the use of technology for testing students' mathematics performance (Logan, 2015); students' challenges while demonstrating mathematics performance and understanding through oral testing (Ianonne \& Simpson, 2015); the relationship between students' performance on conventional assessments and complex mathematical modeling problems (Kartal, Dunya, Diefes-Dux, \& Zawojewski, 2016); as well as creating mathematics performance assessments for multiple student levels.

\section{The utility of feedback for improving math achievement}

The benefits of feedback as the result of formative assessment have been discussed for many years (Wiggins, 1998; Sadler, 1989). Nevertheless, in disciplines such as learning math in general and algebra specifically, few researches have been made in the last five years (11 articles published from 2013 to 2017 according to Google Scholar analytics). For instance, Bokhove and Drijvers (2012) reported positive results in research using automatic feedback for the purposes of learning algebra. This formative intervention was led by 11 
math teachers in Holland, in 15 groups of 12th grade students. Results showed that the use of different feedback facilitated the acquisition of algebraic expertise. Besides, feedback fostered algebra learning by decreasing the number of attempts needed for improving student's performance while solving some exercises. The authors concluded that there is potential in applying different kind of feedback during the learning of algebra.

Mayfield and Glenn (2008) also discussed some advantages while using feedback for algebra learning purposes. In this particular inquiry, the participants were three children (nine, 13, and 14 years old) living in vulnerable, familiar, and emotional conditions. They also presented a low academic achievement status. They were trained at home on six target algebra skills and subsequently received a series of five instructional interventions, such as cumulative practice, tiered feedback, feedback plus solution sequence instruction, review practice, and transfer training. The effects of the interventions on the performance of five problem-solving tasks that required novel combinations of two or more of the target skills were evaluated. Results confirmed that practice of the skills and receiving some feedback with solution sequence instruction increases for some of the problem-solving tasks. It then can be affirmed that the state of the art gives us some confirmation about the relevance of feedback for the purposes of learning algebra.

Considering all the above, two research questions arose:

- How does a performance assessment procedure let teachers understand students' competence progress over time in Advanced Algebra?

- How does a performance assessment procedure benefit students' understanding of their learning process in Advanced Algebra?

\section{Method}

Design. Mixed Methods were used to answer research questions, taking into consideration a sequential model (Creswell \& Clark, 2007).

Context. This study was conducted in a private high school in the city of Monterrey, Mexico. The study began when the school year started. Competencies and subcompetencies related to the Advanced Algebra domain and were established and analyzed with a team of math teachers. Six subcompetencies were developed throughout the course. These definitions allowed us to establish the expected performances, considering the students' progress in the curriculum and their ages. (Bayazit, 2010; Carlson et al., 2010; Godino et al., 2012; Oehrtman et al., 2008; Weigand, 2004).

1. Application of sequences (IM-D1)

2. Integration of steps in the general strategy of solving a problem (IM-D2)

3. Application of forms and characteristics of exponential, logarithmic and conic functions according to the characteristics of the graph (IMD3)

4. $\quad$ Function evaluation (RP-D1)

5. Redefining a function in terms of the number to be evaluated (RP-D2) 
6. Interpretation of the result of an algebraic expression evaluated (IR-D1)

The Advanced Algebra topics that would be studied during the semester were also established. The content of this is as follows:

A. Evaluating a function

B. Identifying functions such as lines, quadratics, and cubics, and their characteristics

C. Composite and inverse functions

D. Rational and piecewise functions

E. Exponential and logarithmic functions

F. Mathematical models: exponential and logarithmic

G. Conic sections: circle, parabola, ellipse, and hyperbola

The first topic is that of evaluating a function, which is understood as the activity of making sense of the numeric output of a function. The second topic is identifying functions such as lines, quadratics, and cubics, and their characteristics, in which the student has to find the mathematical form of a graph and apply some principles. The third topic is composite and inverse functions, in which the student has to relate and solve some algebraic operations to find the composite and inverse functions of an original function.

The fourth topic is rational and piecewise function, where the student has to represent, solve, and interpret rational and piecewise functions and apply some properties from the algebraic expressions to graphs. The fifth topic is exponential and logarithmic functions, where the student has to demonstrate an understanding of exponential and logarithmic functions. The sixth topic is strongly related to the fifth topic, where it is expected that the student will apply all principles obtained in the fifth topic to solve real problems with exponential and logarithmic functions. Finally, the last topic is conic sections, where the student shows an understanding of, analyzes, and solves real problems associated with circles, parabolas, ellipses, and hyperbolas.

To design the open problems of the integrating activities, the concepts of Advanced Algebra were associated with the most related competencies (see Table 1). This relationship was identified from the cognitive tasks necessary to solve a problem involving that concept. For example, if the purpose were to evaluate the concept of a segmented function, the mental processes necessary to solve the problem would be indicated, as would the kind of competencies that would relate most to those cerebral processes. Thus, a rubric was designed (Yachina, Gorev, \& Nurgaliyeva, 2015) to indicate the level of procedural skills (Jupri, Drijvers, \& van den Heuvel-Panhuizen, 2014) shown by the participants, based on their knowledge of one specific concept, and arranged by levels (Kop, Janssen, Drijvers, Veenman, \& van Driel, 2015; Marzano \& Kendall, 2007). The first level, called Retrieval was one in which the student coherently shows, through writing, the procedural skills associated with the concept and the steps related to solving the problem. The second level, called Comprehension, appears when the student correctly completes the entire problem with all the algebraic steps and simplifies the results to give a correct final answer.

Participants. Twenty students out of forty participated in this study. The students were between 15 and 16 years old. They were in a low academic 
achievement situation, as they were required to take Advanced Algebra for the second time, given that they did not pass the course the first time they took it. This condition was similar for all of them. Then, it was decided to work with an experimental (EG) and a control group (CG). EG was conformed by seven students meanwhile CG was conformed by thirteen students.

Data collection. Performance assessment rubric: A performance assessment rubric was designed to establish expected levels to be attained for high school students. A total of three competencies related to the study of Advanced Algebra were defined. For each competency, two subcompetencies were defined. A rubric of six subcompetencies was then finally designed for assessment purposes. The New Taxonomy was used as the theoretical support for establishing expected performance level (Marzano \& Kendall, 2007). It was considered that comprehension was the maximum expected level for each subcompetency, given that students need to explain and symbolize their Advanced Algebra operational understanding. Thus, the rubric was designed along two levels of the New Taxonomy: Retrieval and Comprehension, which were labeled with numbers 1 and 2, respectively. The performance assessment reports (PARs) were given to a total of 34 math homework assignments and projects, including qualitative feedback. Table 1 contains the Advanced Algebra performance rubric.

Interview: For understanding in a more profound way students' perception of how performance assessment procedures helped them to learn and understand Advanced Algebra content, interviews were held with 10 students. For treatment of personal information and confidential reasons, a letter of consent was signed by each student. All conversations were transcribed for research analysis purposes.

Data analysis. In order to use the rubric for performance evaluation process, Competere software was used. This software was useful for obtaining performance assessments reports (PAR) (see Appendix 2). Then, PAR nominal data was analyzed using Excel. Finally, verbatim transcripts from interviews were analyzed using ATLAS TI.

\section{Results}

Performance assessment reports. Thirty-four PARs were prepared based on the rubric (see Appendix 2) to give feedback to students according to the expected performance level. A PAR was given to each participant, both at the start and ending of the semester. Variations of performance level were observed as rising, decreasing, and steady. From Figure 1 through Figure 6, results of both groups are shown according to the assessed subcompetencies. Weighted average are expressed as percentages and have been calculated for each of the subcompetency results. 


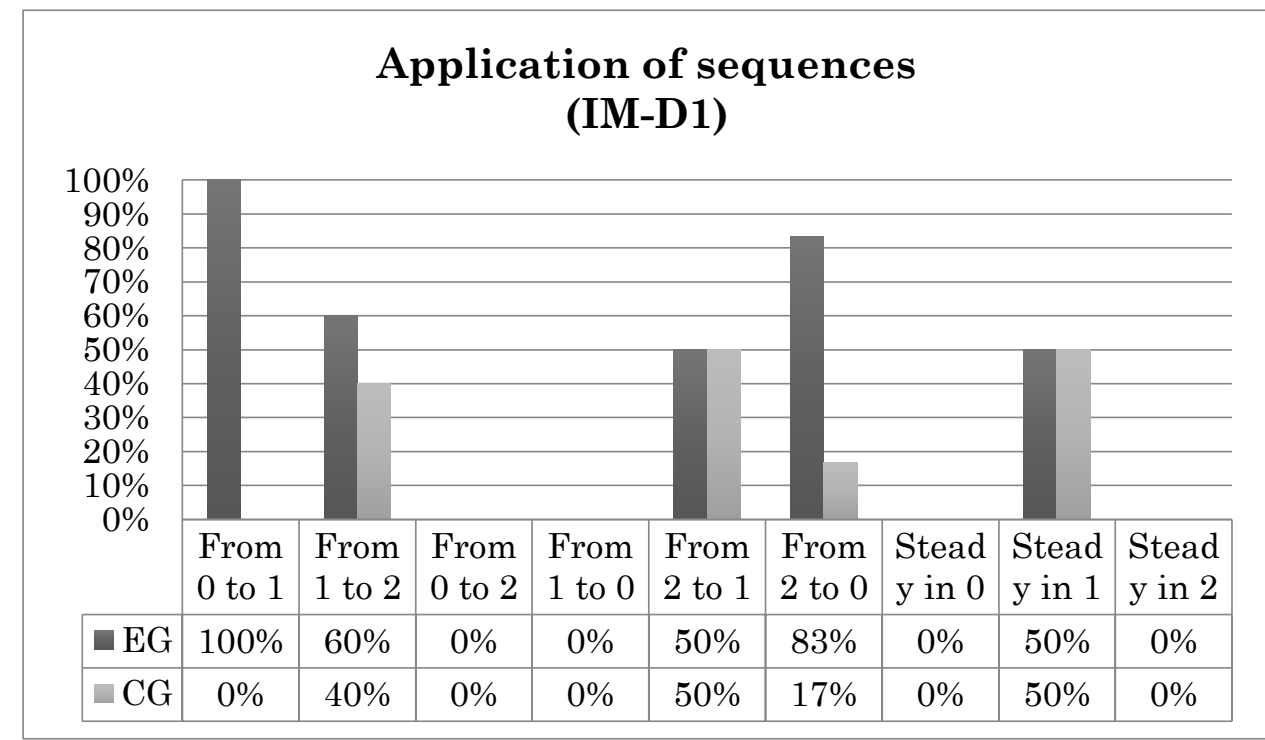

Figure 1. Values obtained after performance evaluation for Application of sequences subcompetency for experimental and control groups.

It can be seen that in this subcompetency (see Figure 1) the outcomes reflect different results. First, a change in level from 2 to level 0 was observed: the experimental group EG reported a decrease of $83 \%$ as opposed to a corresponding $17 \%$ change for the control group CG. On the other hand, there was an increase in the change in performance level from 1 to 2 . The EG reported this change as $60 \%$ of the group, whereas in the case of the CG it was reported as $40 \%$.

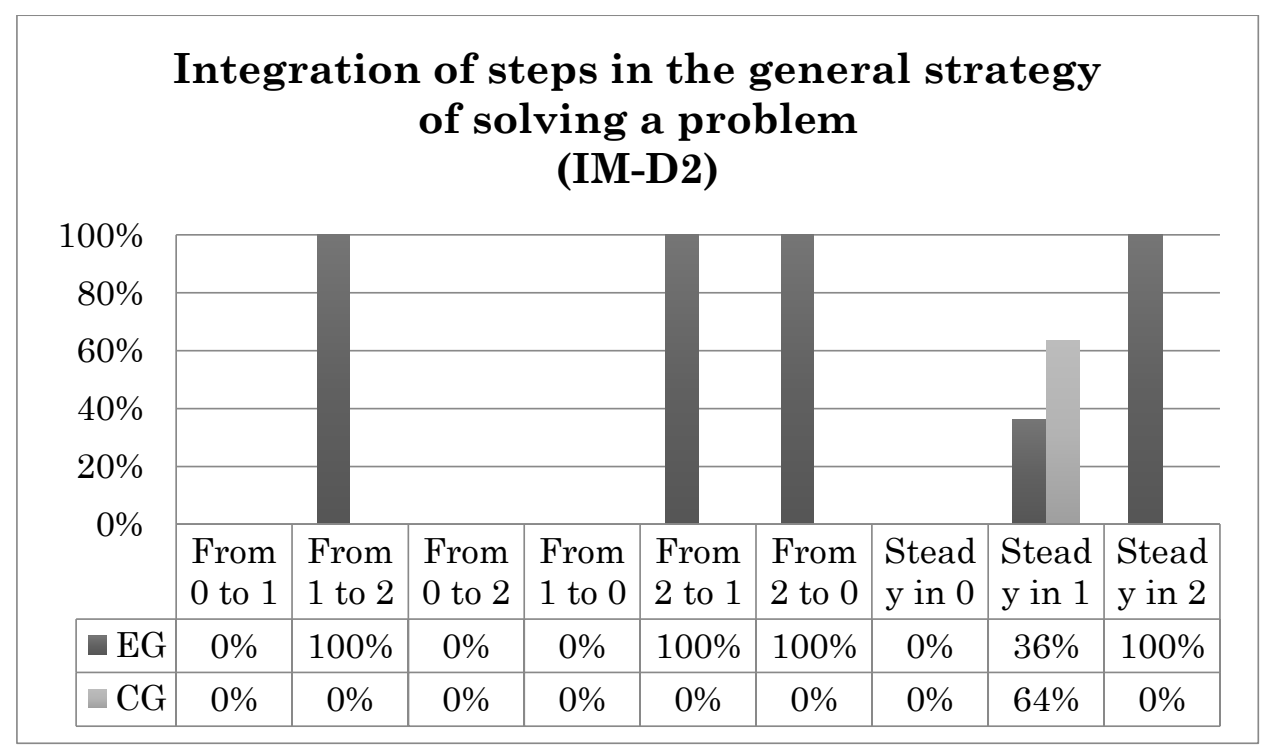

Figure 2. Values obtained after performance evaluation for Integration of steps in the general strategy of solving a problem, for experimental and control groups. 
In this subcompetency (see Figure 2) the performance results tend to remain at the same level or decrease. Thus, the experimental group reported a decrease from level 2 to level 0 of $100 \%$. In addition, permanence in level 1 was also observed. The EG reported $36 \%$ and the CG $64 \%$ for the incidences in this performance level.

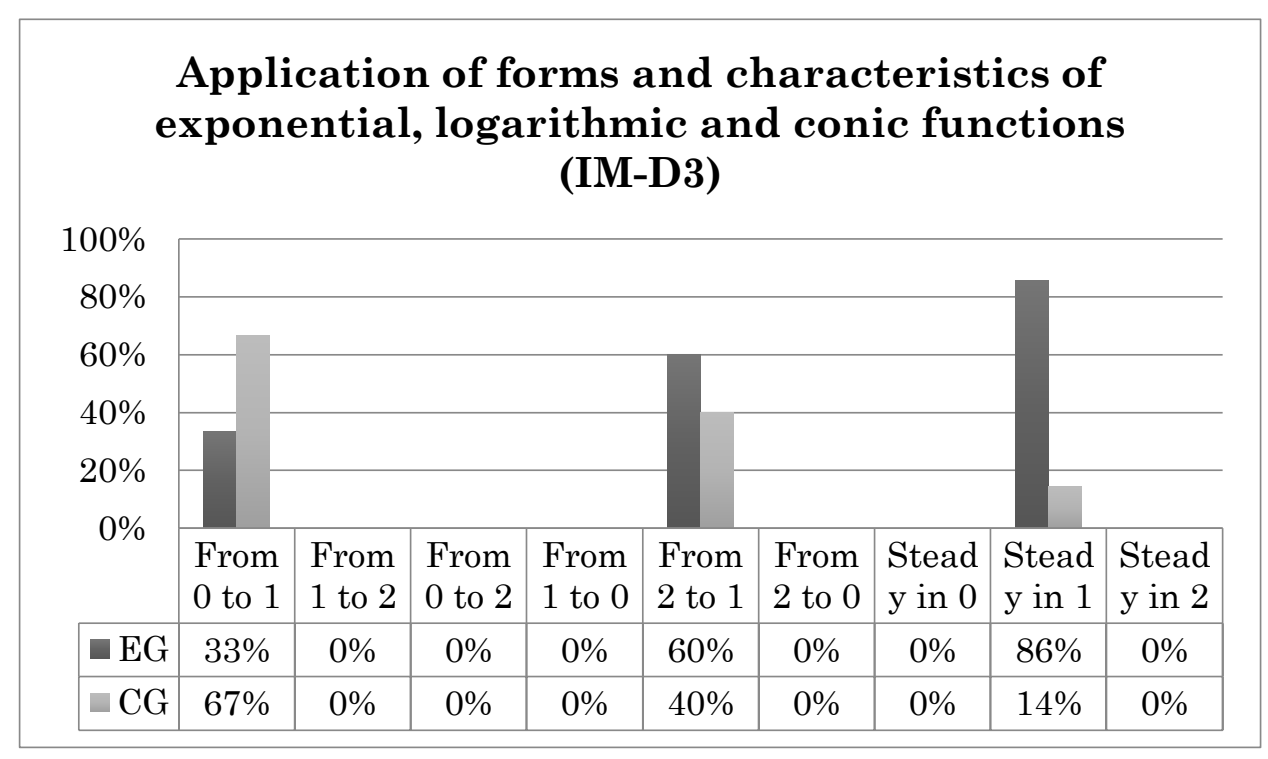

Figure 3. Values obtained after performance evaluation for Application of forms and characteristics of exponential, logarithmic and conic functions according to the characteristics of the graph, for experimental and control groups.

In this subcompetency (see Figure 3) the results also reflect different scopes, as in the subcompetency Application of sequences (see Appendix 2). First, there is a persistence in performance for level 1: the EG reported nearly $86 \%$ as opposed to the $14 \%$ corresponding to the CG. On the other hand, there was a decrease in the performance level change from 2 to 1 . The EG reported this change for $60 \%$ of the group, whereas in the case of the CG it was reported for $40 \%$. However, a slight change can be noticed from the 0 to 1 performance level. Only a very few participants showed improvement in this subcompetency.

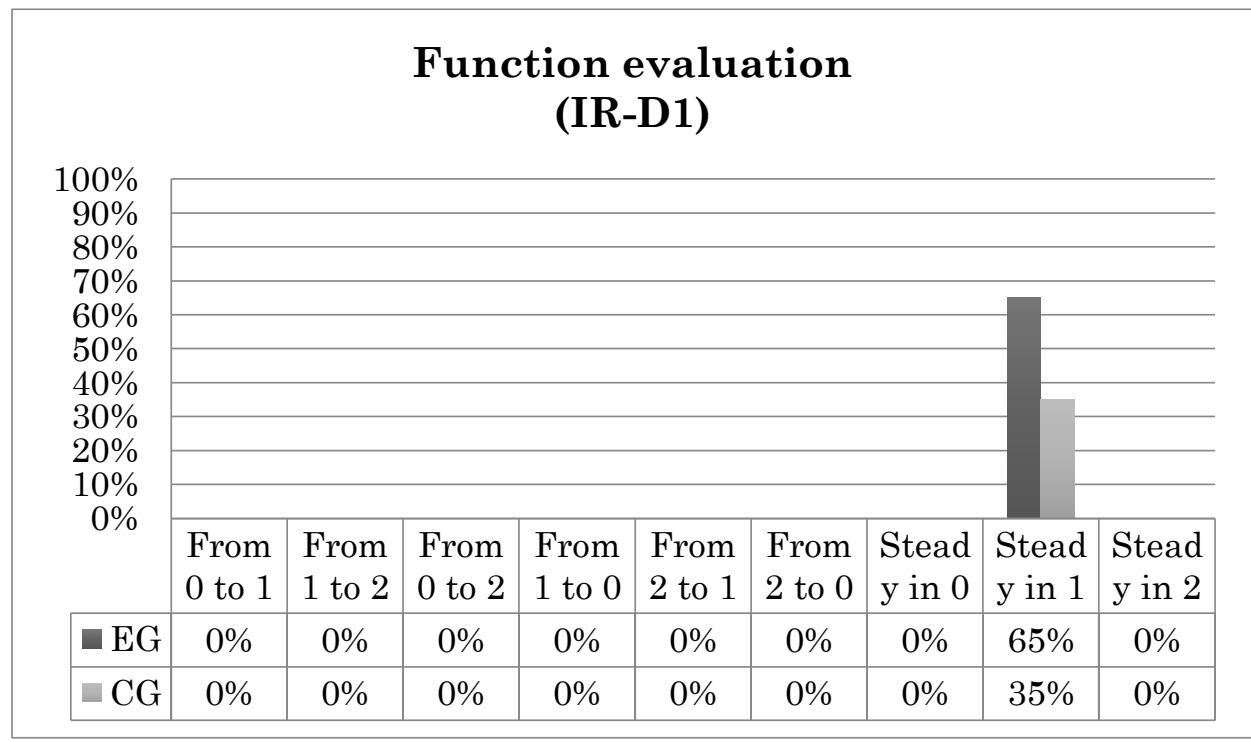


Figure 4. Values obtained after performance evaluation for Function evaluation, for experimental and control groups.

In this subcompetency (see Figure 4) the results show a permanence in performance level 1 . The EG reported $65 \%$, in contrast to a $35 \%$ corresponding to the CG.

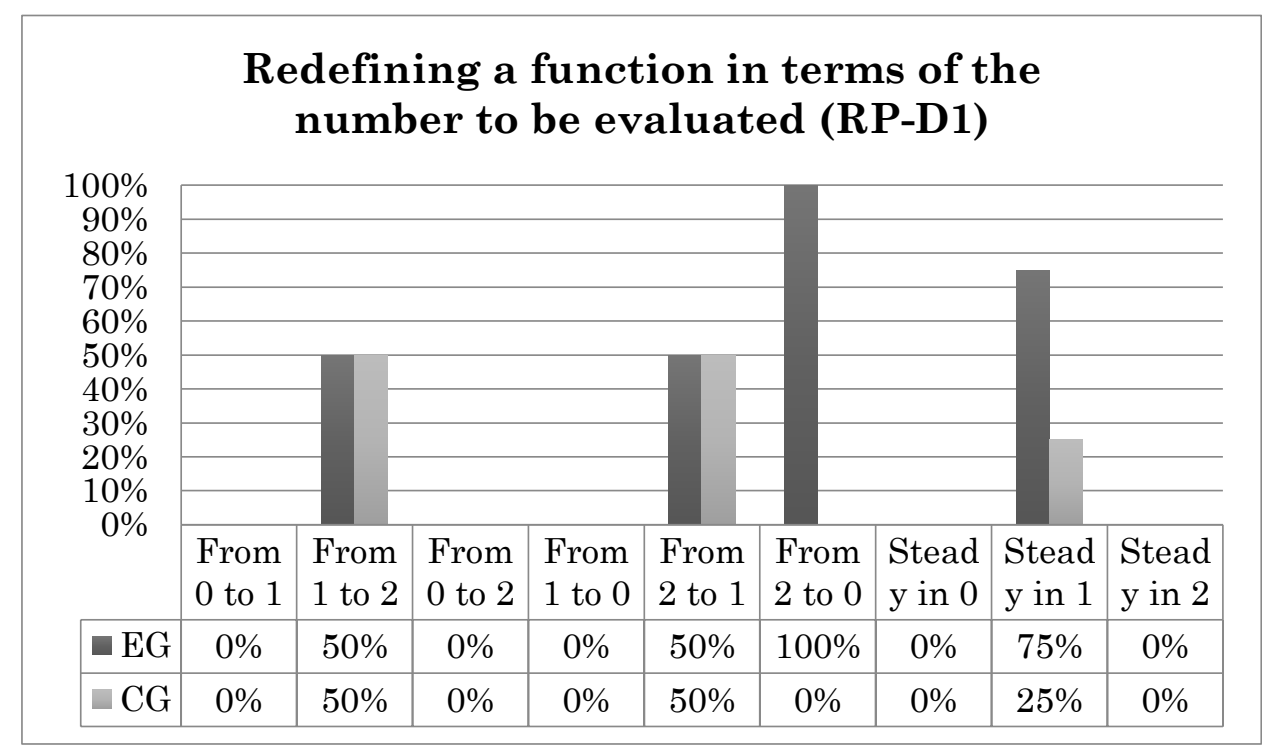

Figure 5. Values obtained after performance evaluation for Redefining a function in terms of the number to be evaluated, for experimental and control groups.

In this case the results are quite different than those shown for other subcompetencies (see Figure 5) because of the variability of results that reflect attained and unattained performance levels. The more remarkable results are that, first, there is a change from level 2 to $0: 100 \%$ of the observed incidences belonged to the EG. Second, in the steady level 1 performance, $75 \%$ of the incidences belonged to the EG, whereas $25 \%$ were in the CG. Third, from performance level 1 to 2 and also from level 2 to $1,50 \%$ of the incidences belonged to both the EG and CG.

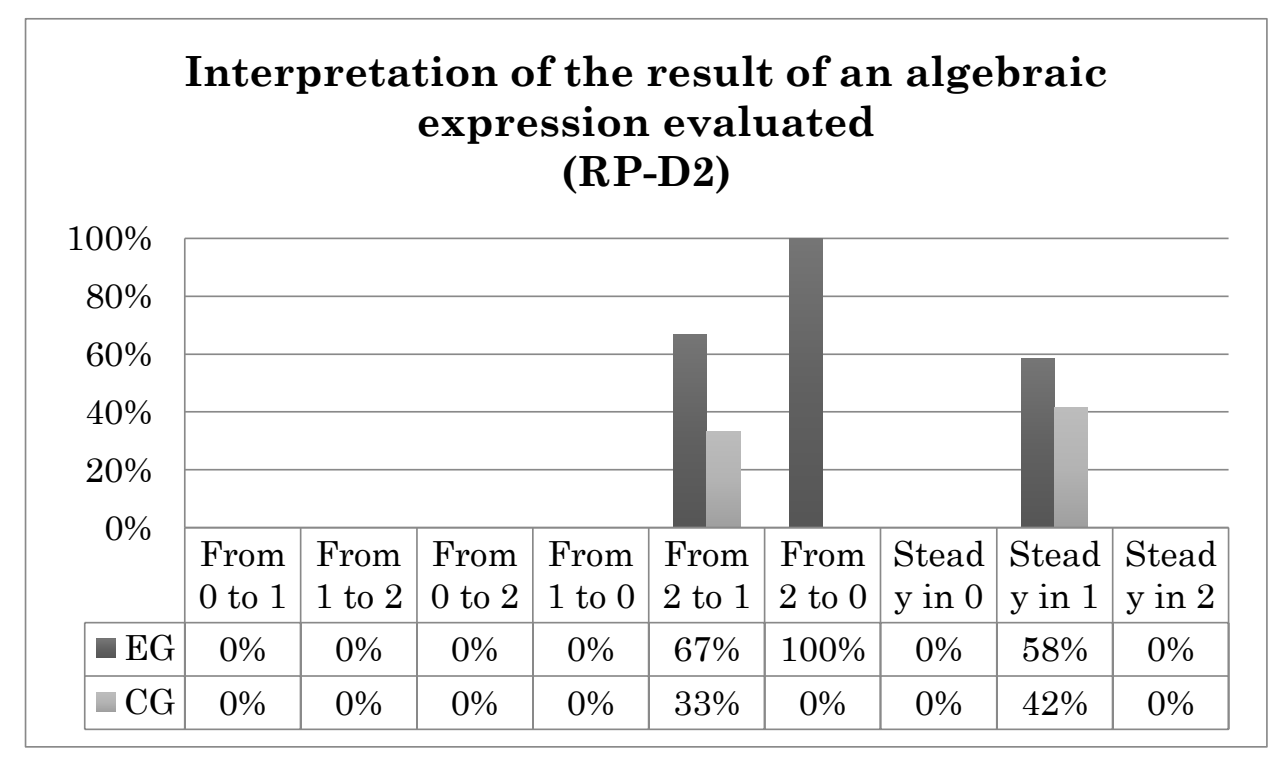


Figure 6. Values obtained after performance evaluation for Interpretation of the result of an algebraic expression evaluated, for experimental and control groups.

In this case, it was noticed that this subcompetency (see Figure 6) showed some results that can be compared to others (e.g., IM-D2 in Figure 2 and RP-D1 in Figure 5). It was observed that from level 2 to 0 all incidences belonged to the EG. Second, from level 2 to 1: $67 \%$ of incidences occurred in the EG; meanwhile $33 \%$ occurred in the CG. And, finally, some participants remained steady in level 1: $60 \%$ of incidences occurred in the EG, whereas $40 \%$ were steady in the CG.

Interviews. Collected data were useful, as it was possible to identify three categories around students' perception of performance assessment benefits and difficulties related to learning and understanding in Advanced Algebra. These categories are as follows: (1) performance evaluation, (2) learning process and (3) reflexive thoughts after understanding PARs.

For the first category, two subcategories were linked: utility and recognition of the student's own strengths and weaknesses. Students from both groups expressed in general that they perceived usefulness in the performance assessment process. For instance: "it is useful, as we sometimes do not realize the misunderstanding we have been experimenting until you catch it in the assessment process" [Henry, Experimental Group ]; "This kind of assessment can help you to improve" [Perla, Control Group].

About recognition of strengths and weaknesses, in both groups, it was perceived as a certain trend to refer to the weaknesses rather than the strengths. Nevertheless, there were some students who expressed a kind of balance between weaknesses and strengths, such as: "Yes, it made me focus on misunderstandings" [Luis, Control Group], and "Ehmmm...it was good to know that in some areas I was doing good and in some other things were bad" [Pedro, Experimental Group].

The second category, learning process, was confirmed by student perceptions of what they thought about themselves as learners, as well as their sense of responsibility for reaching their learning goals. It was useful to understand that some of them, in both groups, thought their Advanced Algebra competencies were good enough in opposition to what their teachers pointed out during performance assessment. For instance: "Mmm... one thing is that what I demonstrate in class and other thing is what I really know. It is possible to make mistakes during class exercises but it doesn't mean I don't know how to do it just for some sign details and stuff like that" [Perla, Control Group]. " Ok, $\mathrm{mmm}$...what I feel is that my teacher is not understanding the way I learn...I mean, the way I process information in my mind; sometimes in class I skip two or three steps by giving the answer, so (bad) results are not matching" [Maria, Experimental Group]. In both cases, teachers of Group A and B point out that Perla and Maria were not reaching the expected subcompetency levels. Figure 7 revealed this statement. 
Maria's radar

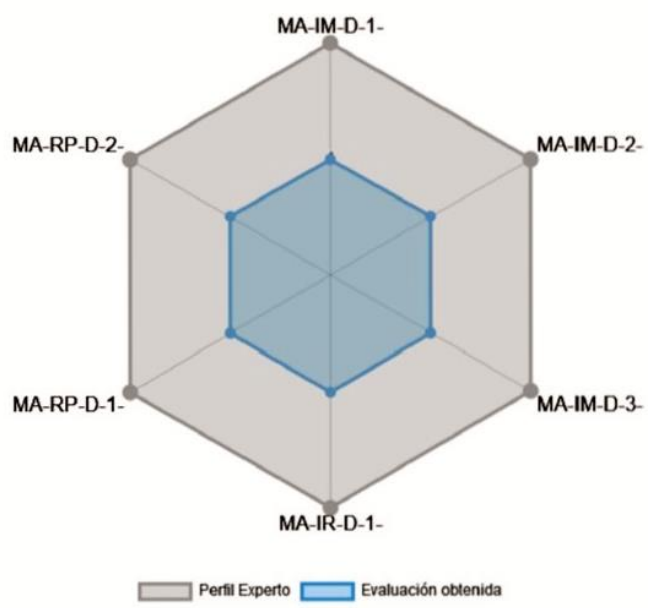

Perla's radar

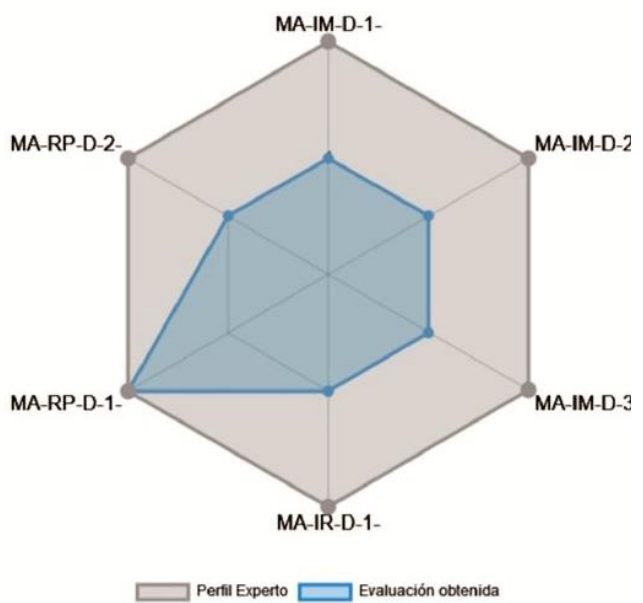

Figure 7. Maria's and Perla's radars included in their respective PARs.

This figure shows progress in levels of performance for two participants, Maria stayed at level 1 , whereas Perla reached level 2 in the subcompetency Redefining a function (RP-D1), in terms of the number to be evaluated. The third category, called reflexive thoughts after understanding PARs, was also illustrative for figuring out students' understanding and emotions regarding their getting their results contained in a PAR. Some students found it easy to distinguish the difference between performance level, qualitative feedback, and the radar graphic (see PAR at Appendix 2). On the other hand, some others didn't understand it quite, so they decided not to read it carefully. In such cases some minutes were devoted to reading it again before the interview. Researchers asked specifically what part of the PAR was difficult to understand. Two opinions were given about the misunderstanding of subcompetency levels expressed within a radar graphic, as for them this kind of drawing was unfamiliar.

Thus, about what they felt, they expressed satisfaction while reading feedback given for each subcompetency by the middle and the end of the period. Some others felt disappointment, sadness, and even frustration. For instance: " While reading it (the PAR), I felt I have to make a bigger effort to improve" [Pedro, Experimental Group]; "After the first one (PAR) I felt worried, but then I realized I have to make some more effort and overcome my mistakes" [Henry, Experimental Group]; " I felt nervous and sad as...as I understood that, even if I thought I could solve the problems, my knowledge was not good enough, and it was a little difficult for me" [Jonathan, Experimental Group].

\section{Discussion}

The results permit the researchers to form a discussion, first around the information collected through the performance assessments themselves and their meaning for learning in Advanced Algebra. Then, the discussion goes over 
the benefits students perceived by the end of the performance assessment process.

Both the competencies "Application of sequences" and "Application forms and characteristics of exponential, logarithmic and conic functions according to the characteristics of the graph" are considered of high importance in the Advanced Algebra domain. Some failures in reaching the required performance level, especially for students of the EG, gave some evidence that their performance level stayed at 1 or went backwards when some more complex problems needed to be solved. These outcomes can be inferred as valuable explanations of poor results in these and other assessed Advanced Algebra subcompetencies within the framework of this study (Bayazit, 2010; Vollrath, 1984). Indeed, the lack of algebraic logic and precision in students' answers provides support for this statement (Gray, Pinto, Pitta, \& Tall, 1999). The lack of mastery of these subcompetencies can be associated with basic mathematical activities in the learning of algebra; for example with the resolution of a problem (Weigand, 2004). The participants of this research studied as a priority the forms and characteristics of the investigated functions. Their results show that they do not fully understand the relation between the graphical form of the functions and the unknowns of the new questions.

On the competency of "Application of forms and characteristics of exponential, logarithmic and conic functions according to the characteristics of the graph," it was found that the students were not showing the expected skills in the activities, such as recognizing, analyzing, completing, and solving (Bayazit, 2010). The knowledge obtained in the classroom through the resolution of activities designed for this purpose was not reflected as part of the student domain by using the graphical features of the exponential, logarithmic, and conic functions.

In the "Integration of steps in the general strategy of solving a problem" subcompetency, it was affirmed that students were not able to show their performance any further than level 1 (Retrievale). This means that they are not able to identify the integration of steps needed to conduct a math operation and a graph analysis in an autonomous way. It may be inferred that students prefer to continue depending on teachers' guidance to do so. This phenomenon confirms Schoenfeld's statements (2007) about the "lack of logic" argument while solving problems.

In the case of "Function evaluation" and "Interpretation of the result of an algebraic expression evaluated" subcompetencies, it was noted in all cases that the Retrieval level was the highest level reached. This means that there is a lack of understanding of abstract concepts. Students are able to identify the concepts, but they are not connected to a meaning. This turns out to be important, based on the fact that these subcompetencies are basic to further precalculus and calculus studies (Godino et al., 2012; Carlson, Oehrtman \& Engelke, 2010). Furthermore, Oehrtman, Carlson \& Thompson et al. (2008) have argued that these subcompetencies are related to the capability of interpreting value changes while processing numeric or algebraic operations. This means being able to change problem conditions and interpret differences between final and alternative results. 
In this research, results showed that some students of the CG and EG did not seem to find the meaning in the intrinsic process of function evaluation, as according to Godino et al. (2012). Another postulate of analysis was that of Carlson \& Thompson (2008), who mentioned that a student can or cannot interpret differences between the initial and final process. The results of these participants showed a lack of skill in the interpretation of function evaluation, which is known by Carlson \& Thompson (2008) as covariational reasoning.

In the case of "Redefining a function in terms of the number to be evaluated" subcompetency, it was affirmed that neither the EG nor CG reached the comprehension level. Some of them even went backwards according to their first performance evaluation results. Based on these results, according to Godino et al. (2012), it may be inferred that students will not be able to understand structures and sequence in a progressive way, which is useful for solving conic function problems. In this research, we found that students lack the ability to reuse the equations of conic functions to change some conditions and bring about a different result. The generation of this equation can be the activity that marks the start of the lack of skill, according to the level of competence shown by the participants. These results confirm the postulates of Godino et al. (2012) on the importance of understanding and managing mathematical structures.

As a complement to the performance assessment results, the interviews allowed the researchers to understand closely what the students were perceiving from the performance assessments and the use of feedback. In most of the cases, feedback was taken as a form of warnings of low performance level, as well as identifiers of areas that needed improvement. Some of the students did improve, but not as much as required.

Moreover, even if feedback was considered useful, as in the study of Mayfield and Glenn (2008), it is difficult to affirm that it really was useful for most of the students of the EG and CG. As a matter of fact, it was revealing that some students think that their teachers do not understand the way they learn while solving Advanced Algebra problems, as Maria and Perla said. It could be inferred that performance feedback for these students was not as meaningful as it was for their pairs.

\section{Conclusions}

It could be affirmed that, in this study, the performance evaluation process put the competencies and subcompetencies that need to be reinforced for Advanced Algebra teachers to improve the learning process, for both groups as well as for each student, into perspective. Getting to understand this learning phenomenon could also be considered valuable for teachers who need to implement the pre-test or learning diagnosis for students who need more orientation in algebra. Indeed, this kind of evaluation could be a good complement for math learning evaluation systems based solely on grades.

The performance evaluation process run in this research also made it clear that it is not enough to demonstrate capabilities around a competency or subcompetency with just a single testing. Results showed that students from both the EG and CG presented some variability in their performance for a single subcompetency from one test to the other. Getting information about students' 
own perceptions as math learners could be another valuable point for teachers, especially when working with young learners.

Learning can be understood in a different way between teachers and students; because of this lack of coincidence, a gap can emerge. Teachers and researchers know that there exists a gap between the curriculum and what students perceive as a learning process. The concept of learning that students have can make it difficult for them to think in a broader way to solve many kinds of mathematical problems. For example, in this research a student said that she knows, but her teacher does not appreciate her way of knowing, and for that reason her teacher does not know that she really knows. Actually this student did not know that her way of solving problems was incomplete and sometimes illogical. How many students with this feeling might we have without noticing it? Maybe the scientific community needs to devote some effort towards researching the concept of learning, and the disposition of high school students towards learning, to gain an understanding of the real situation.

\section{Research limits}

This research was conducted in a single high school. It is recommended that this study be applied in different high schools, both private and public, with some similar standards in terms of competencies for Advanced Algebra learning.

\section{Future research}

There is little research about Advanced Algebra performance assessment. It is necessary to understand in a deeper way how these competencies and subcompetencies reinforce the study and use of this knowledge for students, notably with students in their first year of high school.

It is also necessary to understand from the Novice-Expert theory (Chi, Glasser \&Farr, 1988) how Advanced Algebra competencies have been acquired, so as to foster new strategies and tasks to be taught and developed in class. This kind of research can help students with low performance who need to repeat a course. When a student perceives his or her strengths and low skills, the student can form a team with a peer who has a similar or different condition. Usually these students need to connect what they know with a partner to reinforce their knowledge of the teacher explanation.

Finally, it is suggested that future studies could integrate some research that includes features such as age and academic maturity (Williams, 2000) in connection to context and perception of the student's own learning process in correspondence to math learning goals.

\section{Acknowledgements}

This research study was possible thanks to Novus project "Performance Assessment on Competency Based Learning" and Education Research and Innovation Group of Monterrey Tech. Also, the authors want to thank to Claudia Durand and Sandra Fuentes, high school Mathematics Teachers, for their contribution to the development of this research.

This research was made possible in the framework of the Performance Assessment Project for NOVUS - ITESM (2016-2017). 


\section{Disclosure statement}

The authors reported no potential conflict of interest.

\section{Notes on contributors}

Santa Tejeda, Doctor of Innovation in Education Professor and Researcher, Regional Science Department - Tecnologico de Monterrey (ITESM), Nuevo Leon, México.

Katherina Gallardo, Doctor of Innovation in Education, Professor and Researcher, Humanities and Education School - Tecnologico de Monterrey (ITESM), Nuevo Leon, México.

\section{References}

Bahr, D. L. (2007). Creating Mathematics Performance Assessments that Address Multiple Student Levels. Australian Mathematics Teacher, 63(1), 33-40. Retrieved from: https://eric.ed.gov/?id=EJ769974

Bayazit, I. (2010). The influence of teaching on student learning: The notion of piecewise function. International Electronic Journal of Mathematics Education, 5(3), 146-164.

Bokhove, C., \& Drijvers, P. (2012). Effects of feedback in an online algebra intervention. Technology, Knowledge and Learning, 17(1-2), 43-59. doi:https://doi.org/10.1007/s10758-012-9191-8

Carlson, M., Oehrtman, M., \& Engelke, N. (2010). The precalculus concept assessment: A tool for assessing students' reasoning abilities and understandings. Cognition and Instruction, 28(2), 113-145. http://dx.doi.org/10.1080/07370001003676587

Chi, M. T. H., Glasser, R., \& Farr, M. J. (1988). The nature of expertise. Hillsdale, NJ.: Lawrence Erlbaum Associates, Inc., Publishers.

Creswell, J. W., \& Clark, V. L. P. (2007). Designing and conducting mixed methods research. Thousand Oaks, CA: SAGE Publications.

Dupeyrat, C., Escribe, C., Huet, N., \& Regner, I. (2011). Positive biases in self-assessment of mathematics competence, achievement goals, and mathematics performance. International Journal of Educational Research, 50(4), 241-250. Retrieved from http://0search.proquest.com.millenium.itesm.mx/docview/964175861?accountid $=41938$

Duval, R. (2006). A cognitive analysis of problems of comprehension in a learning of mathematics. Educational Studies in Mathematics, 61(1-2), 103-131. doi:https://doi.org/10.1007/s10649006-0400-z

Frey, B. B., Schmitt, V. L., \& Allen, J. P. (2012). Defining authentic classroom assessment. Practical Assessment, Research \& Evaluation, 17(2). Available online: http://pareonline.net/getvn.asp?v=17\&n=2

Gray, E., Pinto, M., Pitta, D., \& Tall, D. (1999). Knowledge construction and diverging thinking in elementary \& advanced mathematics. In D. Tirosh (Ed.), Forms of mathematical knowledge: Learning and teaching with understanding (pp. 111-133). Dordrecht, Netherlands: Springer Netherlands.

Godino, J. D., Castro, W. F., Aké, L. P., \& Wilhelmi, M. R. (2012). Naturaleza del razonamiento algebraico elemental (The nature of elemetary algebraic reasoning). Boletim de Educação Matemática, 26(42B), 483-511.http://dx.doi.org/10.1590/S0103-636X2012000200005

Hancock, D. (2007). Effects of performance assessment on the achievement and motivation of graduate students. Active Learning in Higher Education, 8(3), 219-231. Retrieve from: http://alh.sagepub.com/content/8/3/219.short

Iannone, P., \& Simpson, A. (2015). Students' views of oral performance assessment in mathematics: straddling the 'assessment of and assessment for learning divide. Assessment \& Evaluation in Higher Education, 40(7), 971-987. 
Jupri, A., Drijvers, P., \& van den Heuvel-Panhuizen, M. (2014). Student difficulties in solving equations from an operational and a structural perspective. Mathematics Education, $9(1)$, 39-55.

Kartal, O., Dunya, B. A., Diefes-Dux, H. A., \& Zawojewski, J. S. (2016). The relationship between students' performance on conventional standardized mathematics assessments and complex mathematical modeling problems. International Journal of Research in Education and Science, 2(1), 239--252. Retrieved from_ http://0search.proquest.com.millenium.itesm.mx/docview/1826538713?accountid $=41938$

Klein-Collins, R. (2013). Sharpening our focus on learning: The rise of competency-based approaches to degree completion. Occasional Paper, 20. Retrieved from: https://pdfs.semanticscholar.org/818d/803c2cac48a729a578f4497543d9eb7aad6d.pdf

Kop, P. M. G. M., Janssen, F. J. J. M., Drijvers, P. H. M., Veenman, M. V. J., \& van Driel, J. H. (2015). Identifying a framework for graphing formulas from expert strategies. The Journal of Mathematical Behavior, 39, 121-134. https://doi.org/10.1016/j.jmathb.2015.06.002

Lesh, R., \& Doerr, H. M. (2003). Foundations of a model and modeling perspective on mathematics teaching, learning, and problem solving. In R. A. Lesh \& H. M. Doerr (Eds.), Beyond constructivism: Models and modeling perspectives on mathematics problem solving, learning, and teaching, (pp. 3-34). Mahwah, NJ: Lawrence Erlbaum Associates, Inc., Publishers.

Logan, T. (2015). The influence of test mode and visuospatial ability on mathematics assessment performance. Mathematics Education Research Journal, 27(4), 423-441. Retrieved from http://0-search.proquest.com.millenium.itesm.mx/docview/1773219202?accountid=41938

Marzano, R. J., \& Kendall, J. S. (2007). The new taxonomy of educational objectives (2nd ed.). Thousand Oaks, CA: Corwin Press.

Mayfield, K. H., \& Glenn, I. M. (2008). An evaluation of interventions to facilitate algebra problem solving. Journal of Behavioral Education, 17(3), 278-302. doi:https://doi.org/10.1007/s10864008-9068-z

Oehrtman, M., Carlson, M., \& Thompson, P. W. (2008). Foundational reasoning abilities that promote coherence in students' function understanding. In M. P. Carlson \& C, Rasmussen (Eds.), Making the connection: Research and teaching in undergraduate mathematics education, (pp. 27-42). Washington, DC: Mathematical Association of America,

Oehrtman, M., Carlson, M., \& Thompson, P. W. (2008). Foundational reasoning abilities that promote coherence in students' function understanding. Making the connection: Research and teaching in undergraduate mathematics education, 27, 42

OCDE (2016). PISA 2015 Mathematics Framwork. Retrieve from: http://edu.hioa.no/pdf/9816021ec005.pdf

Palm, T. (2008). Performance assessment and authentic assessment: A conceptual analysis of the literature. Practical assessment, research \& evaluation, 13(4), 1-11. Retrieve from: http://pareonline.net/getvn.asp? $\mathrm{v}=13 \& \mathrm{n}=4$

Polya, G. (1957). How to solve it: A new aspect of mathematical method (2nd ed.). Princeton, NJ: Princeton University Press.

Sadler, D. R. (1989). Formative assessment and the design of instructional systems. Instructional Science, 18(2), 119-144. doi:https://doi.org/10.1007/BF00117714

Schoenfeld, A. H. (2007). What is mathematical proficiency and how can it be assessed? In A. H. Schoenfeld (Ed.), Assessing mathematical proficiency (pp. 59-73).Cambridge, UK: Cambridge University Press.

Secretaría de Educación Pública (SEP). (2008, March 21). Acuerdo número 444 por el que se establecen las competencias que constituyen el marco curricular común del sistema nacional de bachillerato. Retrieved from: https://www.sep.gob.mx/work/models/sep1/Resource/7aa2c3ff-aab8-479f-ad93db49d0a1108a/a444.pdf

Star, J. R., \& Rittle-Johnson, B. (2009). Making algebra work: Instructional strategies that deepen student understanding, within and between representations. ERS Spectrum, 27(2), 11-18. https://nrs.harvard.edu/urn-3:HUL.InstRepos:4889486 
Vega-Castro, D., Molina, M., \& Castro, E. (2012). Sentido estructural de estudiantes de bachillerato en tareas de simplificación de fracciones algebraicas que involucran igualdades notables (High school students' structural sense in the context of simplification of algebraic fractions that involve notable equations). Revista latinoamericana de investigación en matemática educativa, 15(2), 233-258.

Vinner, S. (1983). Concept definition, concept image and the notion of function. International Journal of Mathematical Education in Science and Technology, 14(3), 293-305. http://dx.doi.org/10.1080/0020739830140305

Vollrath, H. J. (1984). Methodik des Begriffslehrens im Mathematikunterricht. Stuttgart, Germany: Klett,

Weigand, H. G. (2004). Sequences-Basic elements for discrete mathematics. ZDM, 36(3), 91-97. doi:https://doi.org/10.1007/BF02652776

Williams, L. M. (2000). Academic maturity: Qualifications to teach the nurse professionals of the future. Collegian, 74), 19-23. doi:https://doi.org/10.1016/S1322-7696(08)60386-8

Wiggins, G. (1998). Educative assessment. Designing assessments to inform and improve student performance. San Francisco, CA: Jossey-Bass Publishers,

Yachina, N. P., Gorev, P. M., \& Nurgaliyeva, A. K. (2015). Open type tasks in mathematics as a tool for students' meta-subject results assessment. Mathematics Education, 10(3), 211-220. doi: 10.12973/mathedu.2015.116a

\section{Appendix 1}

Performance assessment rubric for Advanced Algebra class

\begin{tabular}{|c|c|c|c|}
\hline Competencies & $\begin{array}{l}\text { Disciplinary } \\
\text { competencies }\end{array}$ & $\begin{array}{c}\text { Advanced } \\
\text { competencies } \\
\text { Level 1: Retrieving }\end{array}$ & $\begin{array}{c}\text { Advanced } \\
\text { competencies } \\
\text { Level 2: } \\
\text { Comprehension }\end{array}$ \\
\hline \multirow{2}{*}{$\begin{array}{l}\text { 1. Interprets } \\
\text { mathematical models } \\
\text { through the } \\
\text { application of } \\
\text { arithmetic, algebraic, } \\
\text { geometric procedures } \\
\text { for the understanding } \\
\text { and analysis of real } \\
\text { or hypothetical } \\
\text { situations. }\end{array}$} & $\begin{array}{l}\text { Application of } \\
\text { sequences (IM-D1) }\end{array}$ & $\begin{array}{l}\text { Identifies the } \\
\text { functions and } \\
\text { variables as elements } \\
\text { of the new function, } \\
\text { besides the algebraic } \\
\text { symbolization that } \\
\text { distinguishes them }\end{array}$ & $\begin{array}{l}\text { I. In addition to } \\
\text { identifying functions } \\
\text { and / or variables, } \\
\text { algebraically simplifies } \\
\text { the new function and } \\
\text { clears the unknown } \\
\text { variable. }\end{array}$ \\
\hline & $\begin{array}{l}\text { Integration of steps in } \\
\text { the general strategy of } \\
\text { solving a problem (IM- } \\
\text { D2) }\end{array}$ & & $\begin{array}{l}\text { II. Graphs the solution } \\
\text { of problems related to } \\
\text { inverse functions or } \\
\text { composite functions } \\
\text { that include rank, } \\
\text { domain and vertex in a } \\
\text { Cartesian plane. Can } \\
\text { also express the answer } \\
\text { in writing. }\end{array}$ \\
\hline
\end{tabular}


2. Solve mathematical problems by applying arithmetic, algebra, and geometry
Application of forms and characteristics of exponential, logarithmic and conic functions according to the characteristics of the graph (IM-D3)

Function evaluation (RP-D1)
Identifies the rational, exponential,

logarithmic and conic functions, but does not give them the appropriate treatment according to their characteristics

Identifies the relationship between elements of a function from basic knowledge of arithmetic

\section{Graphs the} characteristics of the functions exponential, logarithmic, conic

IV. Applies processes of substitution and simplification of compound and logarithmic functions.

Redefining a function in terms of the number to be evaluated (RP-D2)

V. Applies a process of insertion of values to evaluate conical functions.

Identifies the result and describes its value in isolation according to the problem, without relating it to the variables.

VI.Justifies the answer according to the variables of the problem of the piecewise and exponential function.

procedur

contrast them with

established models or result (IR-D1)

real situations

specific to their

experiences.

\section{Appendix 2}

Sample of a Performance Assessment Report in its original language

\section{Evaluación Competere}

Profesor: $\mathrm{xxxxx}$

Fecha: 24/04/2017

Evaluación: 2

Periodo: enero semestral 2017

\section{Alumno: Perla}

\section{Comentario}

Presta atención a esta retroalimentación porque te daré información importante para tu mejor desempeño en el curso de Matemáticas III

Metas de aprendizaje 
Las expectativas de tu desempeño consisten 1) interpretar modelos matemáticos mediante la aplicación de modelos matemáticos 2) resolver problemas matemáticos 3) explicar e interpretar resultados y contrastarlos con situaciones de la vida real.

¿Cómo lo estás haciendo?

En efecto Perla, has aprendido aunque esto no es suficiente, ya que puedes mejorar en: las funciones seleccionadas, parabólica, elíptica y simplificación de funciones. Te recomiendo revisar estos procesos conceptuales a la brevedad.

¿De qué manera se conecta esta actividad con las siguientes?

El dominio de estas competencias te permitirá cursar exitosamente los cursos de matemáticas IV y V, por lo que te ofrecemos esta retroalimentación para impulsar tu aprendizaje.

\begin{tabular}{|c|c|c|c|c|c|c|c|c|}
\hline \multirow[t]{2}{*}{ Clave } & \multirow{2}{*}{$\begin{array}{c}\text { Descripción } \\
\text { subcompete } \\
\text { ncia }\end{array}$} & \multicolumn{4}{|c|}{ Niveles } & \multirow{2}{*}{$\begin{array}{c}\text { Perfi } \\
1\end{array}$} & \multirow{2}{*}{$\begin{array}{l}\text { Evalua } \\
\text { ción }\end{array}$} & \multirow[t]{2}{*}{ Comentario } \\
\hline & & 1 & 2 & 3 & 4 & & & \\
\hline $\begin{array}{l}\text { MA-MI- } \\
\text { D1 }\end{array}$ & $\begin{array}{l}\text { Aplicación } \\
\text { de } \\
\text { secuencias }\end{array}$ & $\begin{array}{l}\text { Identifica las } \\
\text { funciones y } \\
\text { variables } \\
\text { como } \\
\text { elementos de } \\
\text { la nueva } \\
\text { función } \\
\text { además de la } \\
\text { simbolización } \\
\text { algebraica } \\
\text { que las } \\
\text { distingue }\end{array}$ & $\begin{array}{l}\text { Además de } \\
\text { identificar } \\
\text { las } \\
\text { funciones } \\
\text { y/o } \\
\text { variables, } \\
\text { simplifica } \\
\text { algebraica } \\
\text { mente la } \\
\text { nueva } \\
\text { función y } \\
\text { despeja la } \\
\text { variable } \\
\text { incógnita }\end{array}$ & NA & $\begin{array}{l}\mathrm{N} \\
\mathrm{A}\end{array}$ & 2 & 1 & $\begin{array}{l}\text { Necesitas } \\
\text { apropiarte } \\
\text { de la } \\
\text { función } \\
\text { inversa }\end{array}$ \\
\hline $\begin{array}{l}\text { MA-MI- } \\
\text { D2 }\end{array}$ & Integración & $\begin{array}{l}\text { Identifica las } \\
\text { funciones y } \\
\text { variables } \\
\text { como } \\
\text { elementos de } \\
\text { la nueva } \\
\text { función, } \\
\text { además de la } \\
\text { simbolización } \\
\text { gráfica que } \\
\text { las } \\
\text { distinguen }\end{array}$ & $\begin{array}{l}\text { Grafica la } \\
\text { solución de } \\
\text { los } \\
\text { problema } \\
\text { relacionado } \\
\text { s con } \\
\text { funciones } \\
\text { inversas o } \\
\text { funciones } \\
\text { compuestas } \\
\text { en las que } \\
\text { se incluyen: } \\
\text { rango, } \\
\text { dominio y } \\
\text { vértice en } \\
\text { un plano } \\
\text { cartesiano. } \\
\text { Además, } \\
\text { puede } \\
\text { expresar la } \\
\text { respuesta } \\
\text { de forma } \\
\text { escrita }\end{array}$ & NA & $\begin{array}{l}\mathrm{N} \\
\mathrm{A}\end{array}$ & 2 & 1 & $\begin{array}{l}\text { Necesitas } \\
\text { apropiarte } \\
\text { de la } \\
\text { función } \\
\text { seccionada }\end{array}$ \\
\hline MA-MI- & Aplicación & Identifica las & Grafica las & NA & $\mathrm{N}$ & 2 & 1 & Necesitas \\
\hline
\end{tabular}




\begin{tabular}{|c|c|c|c|c|c|c|c|c|}
\hline D3 & $\begin{array}{l}\text { de formas y } \\
\text { característi } \\
\text { cas }\end{array}$ & $\begin{array}{l}\text { funciones } \\
\text { lineal, } \\
\text { cuadrática y } \\
\text { cúbica, } \\
\text { aunque no } \\
\text { les da el } \\
\text { tratamiento } \\
\text { apropiado } \\
\text { según sus } \\
\text { característica } \\
\text { s }\end{array}$ & $\begin{array}{l}\text { caracteríisti } \\
\text { cas de las } \\
\text { funciones } \\
\text { racional y } \\
\text { valor } \\
\text { absoluto en } \\
\text { un plano } \\
\text { cartesiano }\end{array}$ & & $\mathrm{A}$ & & & $\begin{array}{l}\text { apropiarte } \\
\text { de la } \\
\text { función } \\
\text { parabólica }\end{array}$ \\
\hline IR-D-1 & $\begin{array}{l}\text { Interpretaci } \\
\text { ónd el } \\
\text { resultado } \\
\text { de una } \\
\text { expresión } \\
\text { algebraica } \\
\text { evaluada }\end{array}$ & $\begin{array}{l}\text { Identifica el } \\
\text { resultado y } \\
\text { describe } \\
\text { aisladamente } \\
\text { su valor en } \\
\text { función del } \\
\text { problema, sin } \\
\text { relacionarlo } \\
\text { con las } \\
\text { variables }\end{array}$ & $\begin{array}{l}\text { Justifica la } \\
\text { respuesta } \\
\text { en función } \\
\text { de las } \\
\text { variables } \\
\text { del } \\
\text { problema }\end{array}$ & NA & $\begin{array}{l}\mathrm{N} \\
\mathrm{A}\end{array}$ & 2 & 1 & $\begin{array}{l}\text { Necesitas } \\
\text { apropiarte } \\
\text { de la } \\
\text { función } \\
\text { seccionada }\end{array}$ \\
\hline RP-D-1 & $\begin{array}{l}\text { Evaluación } \\
\text { de } \\
\text { funciones }\end{array}$ & $\begin{array}{l}\text { Identifica la } \\
\text { relación } \\
\text { entre } \\
\text { elementos de } \\
\text { una función a } \\
\text { partir de } \\
\text { conocimiento } \\
\text { sbásicos de } \\
\text { aritmética }\end{array}$ & $\begin{array}{l}\text { Aplica } \\
\text { procesos de } \\
\text { sustitución } \\
\text { y } \\
\text { simplificaci } \\
\text { ón de } \\
\text { funciones }\end{array}$ & NA & $\begin{array}{l}\mathrm{N} \\
\mathrm{A}\end{array}$ & 2 & 1 & $\begin{array}{l}\text { Necesitas } \\
\text { apropiarte } \\
\text { de la } \\
\text { simplificció } \\
\text { n de la } \\
\text { función } \\
\text { logarítmica }\end{array}$ \\
\hline RP-D-2 & $\begin{array}{l}\text { Redefinició } \\
\mathrm{n}\end{array}$ & $\begin{array}{l}\text { Identifica la } \\
\text { relación } \\
\text { entre } \\
\text { elementos de } \\
\text { una función a } \\
\text { partir de } \\
\text { conocimiento } \\
\text { s básicos de } \\
\text { la aritmética }\end{array}$ & $\begin{array}{l}\text { Aplica un } \\
\text { proceso de } \\
\text { inserción de } \\
\text { valore a } \\
\text { evaluar }\end{array}$ & NA & $\begin{array}{l}\mathrm{N} \\
\mathrm{A}\end{array}$ & 2 & 1 & $\begin{array}{l}\text { Necesitas } \\
\text { apropiarte } \\
\text { de la } \\
\text { función } \\
\text { elíptica }\end{array}$ \\
\hline
\end{tabular}

\begin{tabular}{|c|c|}
\hline $\begin{array}{l}\text { Clave } \\
\text { subcompetencia }\end{array}$ & Descripción subcompetencia \\
\hline MA-IM-D-1- & Aplicación de secuencias \\
\hline MA-IM-D-2- & Integración \\
\hline MA-IM-D-3- & $\begin{array}{l}\text { Aplicación de formas y } \\
\text { características }\end{array}$ \\
\hline MA-IR-D-1- & $\begin{array}{l}\text { Interpretación del resultado de la } \\
\text { evaluación }\end{array}$ \\
\hline MA-RP-D-1- & Evaluación de funciones \\
\hline MA-RP-D-2- & Redefinición \\
\hline
\end{tabular}

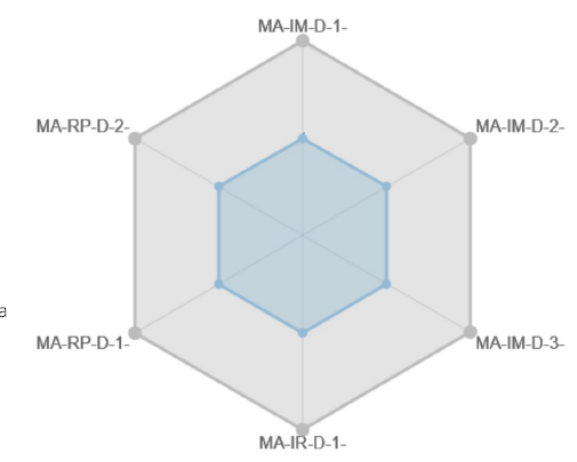

